\title{
Factors associated with the survival rate and the marginal bone loss of dental implant over 7-years loading
}

Jung-Hyeok Choi, Jae-kwon Koh, Eun-Young Kwon, Ji-Young Joo, Ju-Youn Lee, Hyun-Joo Kim Department of Periodontology, School of Dentistry, Pusan National University, Dental Research Institute, Yangsan, Republic of Korea

Erratum to: J Dent Rehabil Appl Sci 2018;34(2):116-26 (https://doi.org/10.14368/jdras.2018.34.2.116)

The article 'Factors associated with the survival rate and the marginal bone loss of dental implant over 7-years loading' authored by Jung-Hyeok Choi, Jae-kwon Koh, Eun-Young Kwon, Ji-Young Joo, Ju-Youn Lee, Hyun-Joo Kim, published in June issue [Vol 34, No 2] of Journal of Dental Rehabilitation and Applied Science (2018), have erratum.

Erratum 1. The author's e-mail was mistakenly given as E-mail: hyunjookim@pusac.ac.kr (Vol 34, No 2, page 116). It should be corrected as E-mail: hyunjookim@pusan.ac.kr

Erratum 2. The author's ORCID was mistakenly given as Ji-Young Joo http://orcid.org/0000-0001-7553-6289 (Vol 34, No 2, page 123). It should be corrected as Ji-Young Joo http://orcid.org/0000-0002-4050-5797.

Erratum 3. The Acknowledgements was mistakenly given as '이 성과는 2017년도 정부(과학기술정보통신부)의 재원으로 한국연구재단의 지원을 받아 수행된 연구임(NRF-2017M3A9B6062026).' (Vol 34, No 2, page 123). It should be corrected as '이 성과는 2017년 도 정부(과학기술정보통신부)의 재원으로 한국연구재단의 지원을 받아 수행된 연구임(NRF-2017M3A9B6062026), 본 연구는 2017 년도 부산대학교 치과병원 임상연구비 지원으로 이루어졌음.'.

The Journal of Dental Rehabilitation and Applied Science apologizes to the readers for this error.

*Correspondence to: Hyun-Joo Kim

Clinical Assistant Professor, Department of Periodontology, School of Dentistry,

Pusan National University, Dental Research Institute, 20 Geumo-ro, Beomeo-ri,

Mulgeum-eup, Yangsan, 50612, Republic of Korea

Tel: +82-55-360-5190, Fax: +82-55-360-5194, E-mail: hyunjookim@pusan.ac.kr
Copyright $\subset 2018$ The Korean Academy of Stomatognathic Function and Occlusion. (c) It is identical to Creative Commons Non-Commercial License. 